\title{
Evaluation of a Warm Mix Asphalt Manufactured with Blast Furnace Slag
}

\author{
Hugo Rondon-Quintana ${ }^{1}$, Saieth Chaves-Pabón ${ }^{2} \&$ Diego A. Escobar ${ }^{3}$ \\ ${ }^{1}$ Universidad Distrital Francisco José de Caldas, Facultad del Medio Ambiente y Recursos Naturales, Bogotá DC., \\ Colombia \\ ${ }^{2}$ Universidad Militar Nueva Granada, Facultad de Estudios a Distancia, Programa de Ingeniería Civil, Bogotá, \\ DC., Colombia \\ ${ }^{3}$ Universidad Nacional de Colombia - Sede Manizales. Facultad de Ingeniería y Arquitectura. Departamento de \\ Ingeniería Civil. Cra 27 \# 64-60, Manizales, 170004, Colombia \\ Correspondence: Carrera 27 \# 64-60, Block I, Office 408, Palogrande Campus, Manizales, Caldas, 17004, \\ Colombia. E-mail: daescobarga@unal.edu.co
}

Received: September 18, 2018

doi:10.5539/mas.v12n12p28
Accepted: October 8, $2018 \quad$ Online Published: November 12, 2018

URL: https://doi.org/10.5539/mas.v12n12p28

\begin{abstract}
The study evaluated the response under monotonic loading (Marshall and indirect traction) and the resistance to moisture damage and abrasion of a warm mix asphalt (WMA) manufactured with an additive called HUSIL, when the coarse fraction of the aggregate was replaced by a blast furnace slag (BFS). In conclusion, it is reported that the additive is capable of reducing the manufacturing temperature of the asphalt mixture by $30^{\circ} \mathrm{C}$. Additionally, the BFS can be used as a partial substitute for the coarse fraction of aggregates in WMA, since when replacing it in $21 \%$, the mixture reach a significant increase in stiffness, resistance to moisture damage, and similar resistance to abrasion with respect to the control asphalt mixture.
\end{abstract}

Keywords: Warm mix asphalt, WMA, blast furmace slag, BFS, chemical additive, HUSIL

\section{Introduction}

\subsection{Warm Mix Asphalt}

According to Sterling (2012), Silva, Oliveira \& Ferreira (2010) and Sharma, Mir \& Farooq (2018), the minimum reduction of the manufacturing temperature, with respect to traditional mixtures of asphalt concrete in the asphalt plant, should be of $28^{\circ} \mathrm{C}, 40^{\circ} \mathrm{C}$ and $25^{\circ} \mathrm{C}$ respectively to be called warm mix asphalt (WMA). This reduces the energy required for the manufacture of asphalt mixtures and polluting emissions into the atmosphere (You \& Goh, 2008, Bonaquist, 2011, Mohammad et al 2015, Sharma, Mir \& Farooq, 2018), helps reduce wear and tear of asphalt plants (Biro, Gandhi \& Amirkhanian, 2009) and decreases the aging of asphalt (Ran et al., 2010; Rondón, Noguera $\&$ Reyes, 2015). Other advantages reported with the use of WMA are: a) they allow their extension and compaction in colder environments (Ran et al., 2010); b) can be used to produce mixtures where the viscosity of the asphalt binder needs to be decreased, for example in asphalt mixtures modified with elastomeric or plastomeric polymers (Liu, Cao \& Fang, 2010, Habal \& Singh, 2017, Singh et al., 2018), recycled RAP type - Reclaimed Asphalt Pavement (Howard, Doyle \& Cox, 2013; Zhao et al., 2015; Kim et al., 2017; Farooq, Mir \& Sharma, 2018) or porous (Frigio et al., 2016); c) the WMA allow to be transported greater distances before being extended and compacted (Robjent \& Dosh, 2009). The WMA can be manufactured by modifying the asphalt or asphalt mix with an additive such as Cecabase, Rediset or Sasobit, among others. They can also be manufactured using asphalt emulsions or foaming asphalt (Zhu, Chen \& Yin, 2017), either with a chemical additive or using special techniques such as WAM-Foam ${ }^{\circledR}$ (Rondón et al., 2015).

\subsection{Blast Furnace Slags (BFS)}

BFS slags are formed when iron ore, coke and flux (either limestone or dolomite) are melted together in a furnace. The typical composition of BFS slags are silica $(\mathrm{SiO} 2)$ and calcium oxide $(\mathrm{CaO})$ (see Table 1). 
Table 1. Chemical composition of blast furnace slag

\begin{tabular}{cccc}
\hline Component & Nassar et al. (2016) & Al-Hdabi \& Al Nageim (2017) & Rondón et al. (2018) \\
\hline $\mathrm{CaO}[\%]$ & 41.42 & 40.37 & 30.83 \\
$\mathrm{SiO} 2[\%]$ & 35.65 & 37.47 & 52.03 \\
$\mathrm{~A} 2 \mathrm{O} 3[\%]$ & 11.21 & 4.76 & 9.90 \\
$\mathrm{P}[\%]$ & - & - & - \\
$\mathrm{MgO}[\%]$ & 6.89 & 3.65 & 0.82 \\
$\mathrm{Na} 2 \mathrm{O}[\%]$ & 0.28 & 2.55 & 0.65 \\
$\mathrm{SO} 3[\%]$ & 2.43 & - & 0.48 \\
$\mathrm{FeO}[\%]$ & - & - & - \\
$\mathrm{Fe}[\%]$ & - & - & - \\
$\mathrm{Fe} 2 \mathrm{O} 3[\%]$ & 0.26 & 0.15 & 1.52 \\
$\mathrm{MnO}[\%]$ & 0.60 & - & 1.26 \\
$\mathrm{TiO} 2[\%]$ & 0.63 & - & 0.98 \\
$\mathrm{~K} 2 \mathrm{O}[\%]$ & 0.64 & 0.62 & 0.86 \\
\hline
\end{tabular}

$\mathrm{SiO} 2$ is normally associated with high hardness and mechanical strength (Muniandy, Aburkaba \& Mahdi, 2013), and $\mathrm{CaO}$ helps increase adhesion with asphalt and contributes to increasing resistance to moisture damage in asphalt mixtures (Muniandy, Aburkaba \& Mahdi, 2013, Al-Rawashdeh \& Sargand, 2014, Modarres \& Rahmanzadeh, 2014, Pasandín \& Pérez, 2015). There are several types of BFS, the most used in previous studies of road projects or in the manufacture of concrete and / or cement are those that are cooled slowly outdoors (called ACBFS, Air-Cooled Blast Furnace Slag) and those that do in a faster way applying cold water jets (called expanded slag). The former are mainly used in construction as coarse aggregate (concrete and filling materials, among others), while the latter are more used in cement production (Rondón et al., 2018, 2018a). There are other types of slag such as steel (SS - Steel Slag) and copper (CS - Copper Slag), which have been more studied compared to the BFS for the manufacture of asphalt mixtures. This is due, perhaps, to the fact that SS and CS are more dense and resistant to abrasion and mechanical loads than BFS (Oluwasola, Hainin \& Aziz, 2015). However, the SS are volumetrically unstable, since they react with water and produce expansion (Wang, Wang \& Gao, 2010).

According to Das et al. (2007), BFS contain little iron, good resistance in contact with acids, exhibit cementing properties and chemical composition similar to clinker, which makes them suitable for use in the manufacture of cement. As advantages of using BFS in asphalt mixtures, the following are reported: 1) they are materials with a rough and porous surface texture that can help improve the adhesion with the asphalt and increase the skid resistance (FHWA, 2008); 2) experience good compatibility with asphalt (Airey, Collop \& Thom, 2004); 3) some studies have reported improvements in resistance to moisture damage, stripping and greater stabilities in the Marshall test (FHWA, 2008); 4) lower unit weight. On the contrary, as disadvantages have been reported (Airey et al., 2004, FHWA, 2008): 1) because they are porous aggregates, they consume more asphalt, which affects the cost; 2) are generally materials with lower resistance to abrasion compared to conventional natural aggregates; 3 ) longer drying times are reported during the production of mixtures in the plant.

Mixtures made from BFS (substitution of natural stone aggregates by BFS) are presented as an environmentally friendly technology. During the last years, the use of recycled materials for the construction of road structures has been increasing in the world. This in order to minimize the use of natural materials, safeguard limited natural resources, contribute to the sustainability of natural resources, reduce the amount of BFS and promote the use of alternative materials as a result of recycling (Das et al., 2007; , Wang \& Gao, 2010; Oluwasola, Hainin \& Aziz, 2015). According to Proctor et al. (2000) and Das et al. (2007), for each ton of iron produced, an amount of blast furnace slag is generated between $220-370 \mathrm{~kg}$ and $340-421 \mathrm{~kg}$, respectively. On the other hand, according to Airey et al. (2004), the annual production of blast furnace slag in the United Kingdom was 4 million tons. The conventional method of eliminating slag is transporting them and depositing them in slag heaps. The above generates an environmental problem, since they occupy spaces within landfills (wasting a material that can be reused) and can release pollutants in air, water and soil (Nouvion et al., 2009). On the other hand, several researches in the world have been carried out, in order to evaluate the use of blast furnace slag in the production of asphalt mixtures. However, the discussion on the subject has not yet finished, as the slags are highly heterogeneous materials (particle shapes and sizes, chemical composition, texture, specific gravity, abrasion resistance and porosity, among others), which develop characteristics and complex properties (Akbarnejad, Houben, \& Molenaar, 2014). 


\subsection{Problem Statement}

In Colombia, a large part of the pavement structures that are designed and constructed are flexible, that is, they have surface layers built with mixtures of the concrete asphalt type. These mixtures have to be manufactured at high temperature. This generates pollutant emissions into the atmosphere (mainly carbon dioxide). In order to solve the aforementioned problems, a more environmentally friendly technology called the warm mix asphalt (WMA) emerges in Germany. Said technology consists in reducing, using additives or special techniques, the temperature of manufacture and compaction of asphalt mixtures (Rondón, Fernández \& Zafra, 2018b). It is important to highlight, based on the literature review carried out, that a study has not yet been documented where a WMA is developed using partial substitution of natural coarse aggregates by BFS. In this sense, the present study leads to present a contribution in this sense.

\subsection{Objective}

The objective of the present research was to measure the resistance under monotonic load and the resistance to moisture damage and abrasion reached by a WMA, manufactured with partial substitutions of the coarse aggregate by BFS. For this purpose, initially an asphalt cement AC type AC 60-70 was modified by wet way with an additive called HUSIL to modify the viscosity and workability characteristics of the base material (asphalt cement), in order to be able to mix it with the coarse aggregate to lower temperatures, and thus manufacture an asphalt mixture that reduces the pollutant load to the atmosphere. The HUSIL foams the asphalt during the manufacturing process at approximately $80^{\circ} \mathrm{C}$ (Rondón, Fernández \& Zafra, 2016, 2018b). Additionally, part of the coarse fraction of the natural aggregate was replaced by a BFS from Acerías Paz del Rio (Colombia). The above, in order to try to produce an asphalt mixture even more friendly to the environment. It was used as reference particle size distribution, that of a mix of asphalt concrete type MDC-19 (widely used for the construction of asphalt layers) in accordance with the Colombian specification of the National Institute of Roads - INVIAS (2013). To achieve the proposed objective, Marshall (AASHTO T 245), indirect traction (AASHTO T 283) and Cantabro (ASTM D7064) tests were performed. The replacement percentages of the coarse fraction of the natural aggregate by BFS were: $12.5 \%$ (replacement of the sieve $1 / 2 "), 21 \%$ (replacement of the sieves $1 / 2$ " and $3 / 8 "$ ) and $43 \%$ (replacement of the sieves $1 / 2 ", 3 / 8 "$ and No. 4).

\section{Materials and Method}

\subsection{Characterization of Materials}

On the AC 60-70 asphalt cement, the natural coarse aggregate and the BFS were performed the typical tests that require the specifications of INVIAS (2013) to characterize them. Table 2 shows the results obtained on the coarse aggregate and the BFS, and Table 3 shows the results obtained on the AC 60-70. It is observed that the materials meet the minimum quality requirements required by the specification INVIAS (2013) to manufacture asphalt concrete mixtures.

Table 2. Characterization of the stone aggregate and BFS

\begin{tabular}{ccccc}
\hline Test & Method & Requirement & Aggregate & BFS \\
\hline Specific gravity coarse aggregate & AASHTO T 84-00 & - & 2.57 & 1.92 \\
Aggregate adsorption & AASHTO T 85-91 & - & $1.95 \%$ & $4.8 \%$ \\
Specific gravity fine aggregates & AASHTO T 84-00 & - & 2.62 & - \\
Fine aggregate adsorption & AASHTO T 85-91 & - & $1.56 \%$ & - \\
Fractured particles: 1 face & ASTM D 5821-01 & $75 \%$ minimum & $95 \%$ & $97 \%$ \\
Liquid and plastic limits & AASHTO T 89-02 & $0 \%$ & $0 \%$ & $0 \%$ \\
Flat and elongated particles & ASTM D 4791-99 & $10 \%$ maximum & $6.7 \%$ & $2.3 \%$ \\
Micro-Deval & AASHTO T327-05 & $25 \%$ maximum & $20.3 \%$ & $26.2 \%$ \\
$10 \%$ fines (dry strength) & DNER-ME 096-98 & $90 \mathrm{kNminimmum}$ & $133 \mathrm{kN}$ & $101 \mathrm{kN}$ \\
Resistance in Los Angeles Machine & AASHTO T 96-02 & $35 \%$ maximum & $23.5 \%$ & $44.5 \%$ \\
\hline
\end{tabular}


Table 3. General characteristics of AC 60-70

\begin{tabular}{|c|c|c|c|c|c|}
\hline \multirow{2}{*}{ Test } & \multirow{2}{*}{ Method } & \multirow{2}{*}{ Unit } & \multicolumn{2}{|c|}{ Requirement (INVIAS,2013) } & \multirow{2}{*}{ Value } \\
\hline & & & Min & Max & \\
\hline \multicolumn{6}{|c|}{ Tests on the original $\mathrm{AC}$} \\
\hline Penetration $\left(25^{\circ} \mathrm{C}, 100 \mathrm{~g}, 5 \mathrm{~s}\right)$ & ASTM D-5 & $0.1 \mathrm{~mm}$ & 60 & 70 & 62.1 \\
\hline Penetration Index & NLT $181 / 88$ & - & -1.2 & +0.6 & -0.19 \\
\hline Softening point & ASTM D-36-95 & ${ }^{\circ} \mathrm{C}$ & 48 & 54 & 52.0 \\
\hline Absolute viscosity $\left(60^{\circ} \mathrm{C}\right)$ & ASTM D-4402 & Poises & 1500 & - & 1852 \\
\hline Specific gravity & AASHTO T 228-04 & - & - & - & 1.011 \\
\hline Viscosity a $135^{\circ} \mathrm{C}$ & AASHTO T-316 & $\mathrm{Pa}-\mathrm{s}$ & - & - & 0.45 \\
\hline Ductility $\left(25^{\circ} \mathrm{C}, 5 \mathrm{~cm} / \mathrm{min}\right)$ & ASTM D-113 & $\mathrm{cm}$ & 100 & - & $>100$ \\
\hline \multicolumn{6}{|c|}{ Tests on the residue of the AC after the RTFOT (Rolling Thin Film Oven Test) } \\
\hline Loss of mass & ASTM D-2872 & $\%$ & - & 0.8 & 0.42 \\
\hline $\begin{array}{l}\text { Penetration }\left(25^{\circ} \mathrm{C}, 100 \mathrm{~g}, 5\right. \\
\mathrm{s}), \% \text { of the original penetration }\end{array}$ & ASTM D-5 & $\%$ & 50 & - & 79 \\
\hline Increase in softening point & ASTM D-36-95 & ${ }^{\circ} \mathrm{C}$ & - & 9 & 7 \\
\hline
\end{tabular}

Additionally, it can be denoted for the natural aggregate that: a) the coarse fraction of the stone aggregate presents good resistance to wear by impact and abrasion, as well as to the fracturing of particles; $b$ ) the shape of the particles is optimal for the manufacture of asphalt mixtures (rounded and fractured faces); c) fine particles are not contaminated by undesirable materials such as clay, organic matter and dust. In the case of the BFS, it is observed that by decreasing the size of the BFS particles, it increases the specific gravity and decreases the absorption. Additionally it is observed that, like the natural aggregate, the BFS presents good resistance to abrasion due to friction between particles and to fracturing under monotonic load in Micro-Deval and $10 \%$ fines tests. However, as reported in the reference literature (p.e., Airey et al., 2004 and FHWA, 2008), the BFS analyzed is a material that experiences low abrasion wear resistance in the Los Angeles machine. It is also observed, as in the natural material, that the BFS presents particles with ideal shapes (rounded but with fractured faces) and no clay content, organic matter or excess dust.

\subsection{Modification of Asphalt Cement}

The AC was modified with the HUSIL chemical additive using a temperature and mixing time of $80{ }^{\circ} \mathrm{C}$ and 5 minutes, respectively (see Figure 1). This temperature was chosen because it foams the asphalt above it. The mixing time was chosen for 5 minutes based on the results of previous studies carried out by (Rondón, Fernández $\&$ Zafra, 2016, 2018b). The physical-chemical properties of the additive can not be presented, since a patent or industrial secret is currently being managed with its use.

The relationship between the content of HUSIL and AC used was HUSIL / CA $=1 \%$ with respect to the mass of the AC. This percentage was chosen based on the results presented in Table 4 where it is observed that: i) the additive increases the specific gravity of the asphalt-additive mixture as the content of HUSIL increases; ii) the asphalt modified with the additive increases its resistance to ignite at high temperatures; iii) the additive tends to stiffen the asphalt remarkably, and the highest stiffness occurs when the additive is added in proportions of HUSIL / $\mathrm{CA}=0.75 \%$ and $1.0 \%$; iv) the ductility decreases logically, since the additive becomes stiff when cooling of the modified asphalt occurs after it has foamed.

Additionally, on conventional and modified asphalt (using HUSIL / CA $=1 \%$ ), a rheological characterization phase was carried out at high and intermediate service temperatures (see Tables 5 and 6, respectively), using a Dynamic Shear Rheometer (DSR, AASHTO T 315). As a result of the tests, the complex shear modulus ( $\mathrm{G}^{*}$ ) and the phase angle $(\delta)$ were obtained. It is reported that the degree of performance at high and intermediate service temperatures of the reference asphalt AC 60-70 (without additive, HUSIL/CA $=0 \%)$ is $58^{\circ} \mathrm{C}\left(\mid \mathrm{G}^{*} / \sin \delta>1.0 \mathrm{kPa}\right.$ for asphalt without aging and $\mid \mathrm{G}^{*} / / \sin \delta>2.2 \mathrm{kPa}$ for aged asphalt in RTFOT $)$ and $22^{\circ} \mathrm{C}\left(\left|\mathrm{G}^{*}\right| \sin \delta<5000 \mathrm{kPa}\right.$ for aged asphalt in RTFOT + PAV), respectively (RTFOT and PAV - Pressure Aging Vessel, refers to short-term aging in rotary thin-film furnace and long-term aging in vessels under pressure, respectively). 
a)

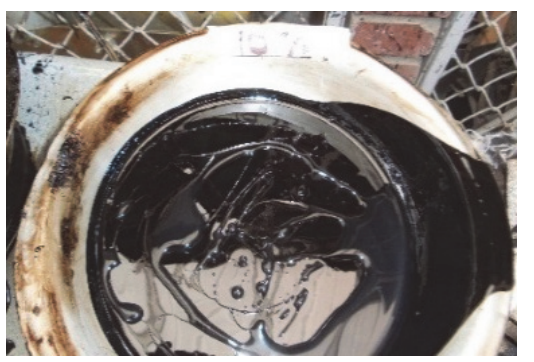

b)

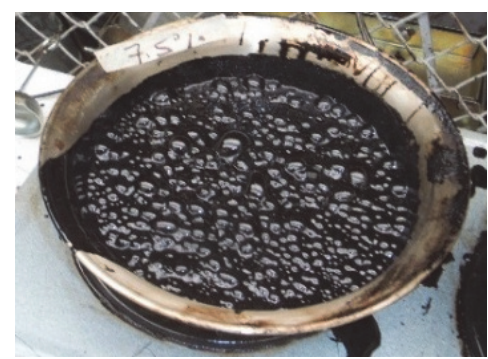

Figure 1. a) HUSIL additive on the asphalt; b) foamed bitumen with the additive at $80^{\circ} \mathrm{C}$

Table 4. Characterization of AC 60-70 modified with HUSIL

\begin{tabular}{cccccc}
\hline $\begin{array}{c}\text { HUSIL/AC } \\
{[\%]}\end{array}$ & $\begin{array}{c}\text { specific weight } \\
{[-]}\end{array}$ & $\begin{array}{c}\text { Penetration } \\
{[\mathbf{m m} / \mathbf{1 0}]}\end{array}$ & Softening point $\left[{ }^{\circ} \mathbf{C}\right]$ & $\begin{array}{c}\text { Ductility } \\
{[\mathbf{m m}]}\end{array}$ & $\begin{array}{c}\text { Flash point } \\
{\left[{ }^{\circ} \mathbf{C}\right]}\end{array}$ \\
\hline 0.0 & 1.0120 & 65.0 & 44.3 & 142.5 & 326 \\
0.5 & 1.0230 & 48.8 & 53.3 & 87.5 & 333 \\
1.0 & 1.0300 & 41.3 & 52.5 & 49.0 & 343 \\
2.5 & 1.0316 & 43.2 & 49.0 & 46.5 & 354 \\
5.0 & 1.0300 & 48.3 & 48.3 & 65.5 & 384 \\
7.5 & 1.0361 & 50.1 & 47.7 & 68.5 & 390 \\
10.0 & 1.0451 & 52.3 & 47.4 & 80.0 & 404 \\
\hline
\end{tabular}

Table 5. Rheological characterization of asphalt AC 60-70

\begin{tabular}{|c|c|c|c|c|c|}
\hline $\begin{array}{c}\text { Temperature } \\
{\left[{ }^{\circ} \mathrm{C}\right]}\end{array}$ & $\begin{array}{l}\text { Frequency } \\
\text { [ rad/s] }\end{array}$ & $\begin{array}{c}\delta \\
{[\circ]}\end{array}$ & $\begin{array}{l}\text { G* }_{[\mathrm{Pa}]}^{*} \\
\end{array}$ & $\begin{array}{c}\left|\mathbf{G}^{*}\right| / \sin \delta \\
{[\mathrm{kPa}]}\end{array}$ & $\begin{array}{c}\left|G^{*}\right| \cdot \sin \delta \\
{[\mathrm{kPa}]}\end{array}$ \\
\hline \multicolumn{6}{|c|}{ AC 60-70 not aged } \\
\hline 58 & 10 & 87 & 2470 & 2.473 & 2.467 \\
\hline 64 & 10 & 88 & 1002 & 1.00 & 1.00 \\
\hline 70 & 10 & 89 & 453 & 0.453 & 0.453 \\
\hline \multicolumn{6}{|c|}{ AC 60-70 aged in en RTFOT } \\
\hline 52 & 10 & 83 & 11062 & 11.15 & 10.98 \\
\hline 58 & 10 & 85 & 4276 & 4.29 & 4.26 \\
\hline 64 & 10 & 87 & 1701 & 1.70 & 1.70 \\
\hline \multicolumn{6}{|c|}{ AC 60-70 aged in RTFOT + PAV } \\
\hline 16 & 10 & 44 & 14266000 & 20537 & 9910 \\
\hline 19 & 10 & 45 & 10193000 & 14415 & 7208 \\
\hline 22 & 10 & 47 & 6659000 & 9105 & 4870 \\
\hline
\end{tabular}

Table 6. Rheological characterization modified asphalt with HUSIL

\begin{tabular}{|c|c|c|c|c|c|}
\hline $\begin{array}{c}\text { Temperature } \\
{\left[{ }^{\circ} \mathrm{C}\right]} \\
\end{array}$ & $\begin{array}{c}\text { Frequency } \\
{[\mathbf{r a d} / \mathrm{s}]}\end{array}$ & $\begin{array}{c}\delta \\
{\left[{ }^{\circ}\right]}\end{array}$ & $\begin{array}{l}\mathrm{G}^{*} \\
{[\mathrm{~Pa}]}\end{array}$ & $\begin{array}{c}\left|\mathrm{G}^{*}\right| / \sin \delta \\
{[\mathrm{kPa}]} \\
\end{array}$ & $\begin{array}{c}\left|\mathrm{G}^{*}\right| \cdot \sin \delta \\
{[\mathrm{kPa}]}\end{array}$ \\
\hline \multicolumn{6}{|c|}{ AC 60-70 modified with HUSIL/AC $=1 \%$ non-aged } \\
\hline 64 & 10 & 66.5 & 2358.3 & 2.57 & 2.16 \\
\hline 70 & 10 & 69 & 1280.5 & 1.37 & 1.20 \\
\hline 76 & 10 & 70 & 888.2 & 0.95 & 0.83 \\
\hline \multicolumn{6}{|c|}{ AC 60-70 modified with HUSIL/AC $=1 \%$. non-aged RTFOT } \\
\hline 64 & 10 & 72.4 & 8685 & 9.11 & 8.28 \\
\hline 70 & 10 & 76.3 & 4072 & 4.19 & 3.96 \\
\hline 76 & 10 & 79.8 & 1899 & 1.93 & 1.87 \\
\hline \multicolumn{6}{|c|}{ AC 60-70 modified with HUSIL/AC $=1 \%$. aged in RTFOT + PAV } \\
\hline 16 & 10 & 31.5 & 11700000 & 22392 & 6113 \\
\hline 19 & 10 & 32.6 & 8570000 & 15907 & 4617 \\
\hline 22 & 10 & 33.9 & 6150000 & 11027 & 3430 \\
\hline
\end{tabular}


For the case of asphalt AC 60-70 modified with HUSIL at 1\%, the performance grade at high service temperatures increased to $70^{\circ} \mathrm{C}$, which is an indicator of a binder more resistant to phenomena such as rutting in high temperature climates. Additionally, at intermediate temperatures, the performance grade improved (decreased from 22 to $19^{\circ} \mathrm{C}$ ), perhaps because the additive increases the resistance of the asphalt to aging.

\subsection{Marshall Test-Control Asphalt Mixture}

In order to carry out the Marshall test (AASHTO T 245) of the control MDC-19 mixture (without additive and without substitution of natural aggregates by BFS, HUSIL / $\mathrm{AC}=0 \%$ ), five briquettes were manufactured (compacted to 75 blows per face) for each asphalt percentage of $4.5 \%, 5.0 \%, 5.5 \%$ and $6.0 \%$. The mixing and compaction temperatures were $150^{\circ} \mathrm{C}$ and $140^{\circ} \mathrm{C}$, respectively. These temperatures were chosen based on the viscosity test carried out on AC 60-70, complying with the specified range for dense type mixtures (mixture viscosity of $170 \mathrm{cp}$ and compaction of $280 \mathrm{cp}$ ). The particle size distribution of the MDC-19 mixture is presented in Table 7.

\subsection{Marshall Test on Asphalt Mixtures}

In order to carry out the Marshall test (AASHTO T 245) of the control MDC-19 mixture (without additive and without substitution of natural aggregates by BFS, HUSIL / $\mathrm{AC}=0 \%$ ), five briquettes were manufactured (compacted to 75 blows per face) for each asphalt percentage of $4.5 \%, 5.0 \%, 5.5 \%$ and $6.0 \%$. The mixing and compaction temperatures were $150^{\circ} \mathrm{C}$ and $140^{\circ} \mathrm{C}$, respectively. These temperatures were chosen based on the viscosity test carried out on AC 60-70, complying with the specified range for dense type mixtures (mixture viscosity of $170 \mathrm{cp}$ and compaction of $280 \mathrm{cp}$ ). The particle size distribution of the MDC-19 mixture is presented in Table 7.

\subsection{Marshall Test on asphalt mixtures with BFS}

Using the optimum percentage of asphalt obtained from the design of the control mixture, new MDC-19 briquettes were prepared, replacing the coarse fraction of the natural coarse aggregate with BFS. The replacement proportions of the coarse aggregate were $0 \%$ (control mixture manufactured with $100 \%$ natural aggregate), $12.5 \%(1 / 2$ " sieve replacement), $21 \%$ (replacement of sieves $1 / 2 "$ and $3 / 8 "$ ) and $43 \%$ (replacement of sieves $1 / 2 ", 3 / 8$ " and No. 4 ).

Table 7. Particle size distribution of the coarse aggregates for MDC-19 mixture (INVIAS, 2013)

\begin{tabular}{cccc}
\hline Sieve & Sieve $[\mathbf{m m}]$ & \% passing & \% retained \\
\hline $1 "$ & 25.00 & 100.0 & 0.0 \\
$3 / 4^{\prime \prime}$ & 19.00 & 87.5 & 12.5 \\
$1 / 2^{\prime \prime}$ & 12.50 & 76.0 & 11.5 \\
$3 / 8^{\prime \prime}$ & 9.50 & 68.5 & 7.5 \\
4 & 4.75 & 51.0 & 17.5 \\
10 & 2.00 & 37.0 & 14.0 \\
40 & 0.43 & 19.5 & 17.5 \\
80 & 0.18 & 12.5 & 7.0 \\
200 & 0.075 & 6.0 & 6.5 \\
Bottom & - & 0.0 & 6.0 \\
\hline
\end{tabular}

\subsection{Indirect Tensile Test and Resistance to Moisture Damage}

The indirect tensile test (AASHTO T 283) was performed on the control mixture and on the other three with replacements of natural aggregate by BFS described above (replacement of the coarse fraction of $12.5 \%, 21 \%$ and $43 \%$ ). Each evaluated mixture was tested under dry conditions - ITD ( 3 samples per type mix) and saturated - ITS ( 3 samples per type of mixture, submerged in water for two months). With the results of the test, the relationship between the saturated and dry condition (ITS / ITD) was calculated in order to further assess the moisture damage. The air void content used was that which was obtained based on the manufacture of the mixtures using the optimum content of asphalt and compacting the briquettes to 75 blows per side (the range of air voids specified by AASHTO T 283 of $6 \%$ to $8 \%$ was not used).

\subsection{Cantabro Test}

The Cantabro test (ASTM D7064) was carried out on the control mixture and the mixtures with substitution of the 
coarse fraction of the aggregate by BFS $(12.5 \%, 21 \%$ and 43$)$. The test was carried out under a temperature of $25^{\circ}$ $\mathrm{C}$ in the Los Angeles machine (without the steel spheres), using 300 revolutions to measure the loss of mass due to abrasion wear. Three samples per type of mixture were tested in this stage. This test was carried out in order to evaluate the abrasion resistance and to the disintegration under a mechanical load (Cox et al., 2017).

\subsection{Test on WMA with BFS}

For the manufacture of warm asphalt mixtures, as mentioned above, the percentage of HUSIL additive chosen was $1 \%$ with respect to the asphalt mass and it was decided to decrease the mixing temperature by $30^{\circ} \mathrm{C}$ based on previous studies reported by Rondón, Fernández \& Zafra $(2016,2018 b)$. That is, WMA were manufactured at $120^{\circ}$ C. The briquettes were of the Marshall type (1200 g, compacted to 75 blows per side) and the optimum asphalt content was used. Two mixtures were manufactured using the additive under temperature of $120^{\circ} \mathrm{C}$ (WMA): control (100\% natural aggregate) and the one that replaced $21 \%$ of the natural aggregate by BFS (replacement of the sieves 1/2" and 3/8"). The Marshall (AASHTO T 245, 5 samples per type of mixture), indirect traction (AASHTO T 283, 3 dry samples and 3 submersed in water per type of mixture) and Cantabro (ASTM D7064, 3 samples per type of mixture) tests were carried out again on these two warm mixes.

\section{Results}

\subsection{Marshall Test-Control Mixture}

Table 8 shows the summary of the results of the Marshall test performed on the control mixture (without additive and without substitution of natural agreggate by BFS).

Table 8. Summary of the Marshall test performed on the MDC-19 control mixture.

\begin{tabular}{ccccccc}
\hline AC $[\%]$ & $\begin{array}{c}\text { Stability - S } \\
{[\mathbf{k N}]}\end{array}$ & $\begin{array}{c}\text { Flow - F } \\
{[\mathbf{m m}]}\end{array}$ & $\begin{array}{c}\text { S/F } \\
{[\mathbf{k N} / \mathbf{m m}]}\end{array}$ & Va [\%] & VMA [\%] & VFA [\%] \\
\hline 4.5 & 11.35 & 3.89 & 2.92 & 5.9 & 16.1 & 63.2 \\
5.0 & 12.79 & 3.61 & 3.55 & 5.3 & 16.6 & 67.9 \\
5.5 & 13.62 & 3.51 & 3.89 & 4.2 & 16.7 & 74.8 \\
6.0 & 12.28 & 3.86 & 3.18 & 3.3 & 17.0 & 80.4 \\
\hline
\end{tabular}

Based on the results, 5.5\% asphalt is established as the optimum percentage. This asphalt content was defined based on the criteria established by INVIAS (2013), air voids - ranging between $4 \%$ and $6 \%$, volume in mineral aggregates - minimum VMA of $15 \%$ and voids filled with asphalt - VFA between $65 \%$ and $75 \%$, and taking into account that with $5.5 \%$ the highest resistance is reported under monotonic load $(\mathrm{S}, \mathrm{S} / \mathrm{F})$ and the lowest displacement in the fault state (flow - F).

\subsection{Marshall Test Mixes with BFS}

Figures 2 and 3 show the results of the Marshall test performed on mixtures containing replacements of the coarse fraction of natural aggregate by BFS. In general terms, the following may be denoted: i) it is observed that when replacing the natural aggregate with BFS, the air voids increase; ii) despite the above, when the optimum asphalt content of $5.5 \%$ is used and $21 \%$ of the aggregate is replaced, the resistance under monotonic load evaluated through the stability (S) and the $\mathrm{S} / \mathrm{F}$ ratio is greater with respect to the control mixture, and the VMA and VFA comply with the range established by the specification INVIAS (2013); iii) when a 43\% substitution of the aggregate is used by BFS, the resistance under monotonic load decreases markedly with respect to the control mixture, mainly due to the high content of voids.

\subsection{Indirect Tensible Test}

In Table 9, the results of the indirect tensile test are presented. It is observed that the best behaviors were reached by the mixtures manufactured with coarse aggregate substitution by BFS of $12.5 \%$ and $21 \%$, since both tensile strengths (dry condition - ITD and saturated - ITS) and the ratio TSR = ITS / ITD were superior to that of the control mixture, although air voids were larger and the asphalt content was the same. The above is perhaps due to the fact that the asphalt adhered more easily with the BFS due to its greater porosity and absorption compared to the natural aggregate. For the case of the mixture with substitution of $43 \%$ of aggregate by BFS, the indirect tensile strength and moisture damage is lower compared to the control mixture due mainly to the higher content of voids since the asphalt content is insufficient to properly adhere the aggregates and the BFS. 


\subsection{Cantabro Test}

Table 10 shows the results of the Cantabro test. A greater loss due to abrasion is observed when the natural aggregate is replaced by BFS, and this loss is greater as the substitution content is higher. The above is mainly due to the greater porosity of the mixtures that use BFS and to the fact that said materials have lower resistance to abrasion compared to the natural aggregate.

\subsection{Test on Warm Asphalt Mixtures}

Table 11 presents the results obtained from the Marshall, indirect traction and Cantabro tests carried out on WMA mixtures manufactured with the HUSIL additive at a mixing temperature of $120^{\circ} \mathrm{C}$. These mixtures were called WMA-Control for the case where there was no substitution of the natural aggregate and WMA-BFS when $21 \%$ of the natural aggregate was replaced by BFS (replacement of sieves $1 / 2$ " and 3/8").

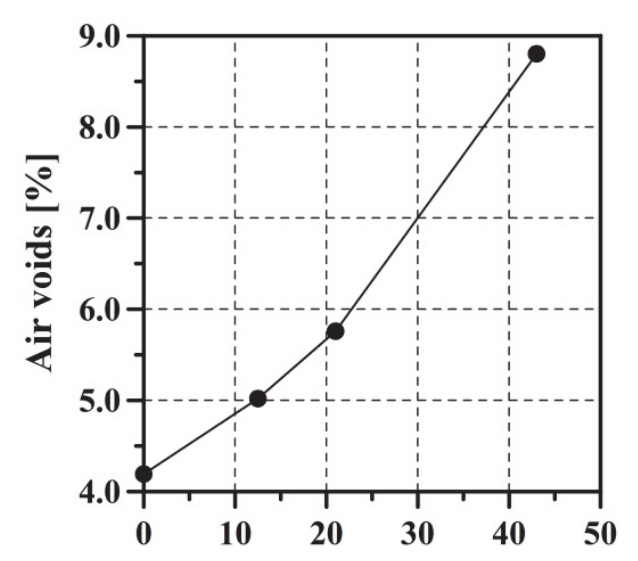

a) Aggregate replacement by BFS [\%]

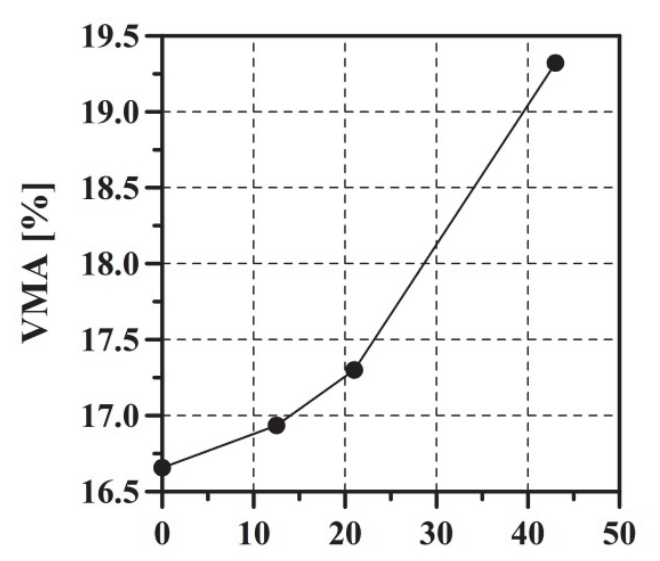

b) Aggregate replacement by BFS [\%]

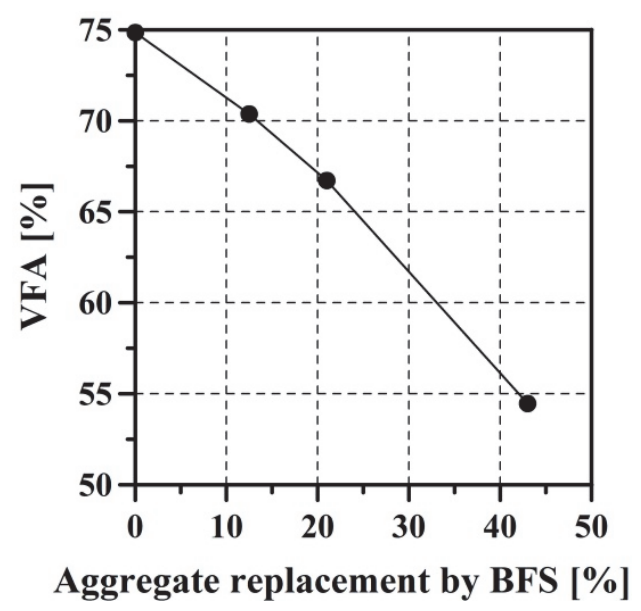

Figure 2. Evolution of a) Va, b) VMA and c) VFA with the replacement of the aggregate by BFS. 


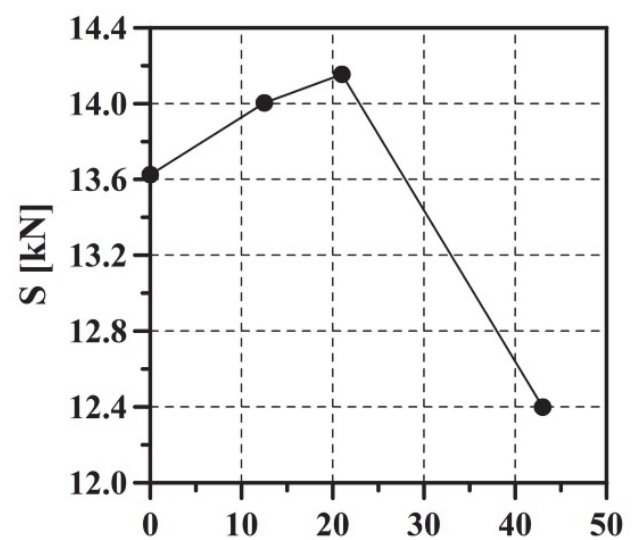

a) Aggregate replacement by BFS [\%]

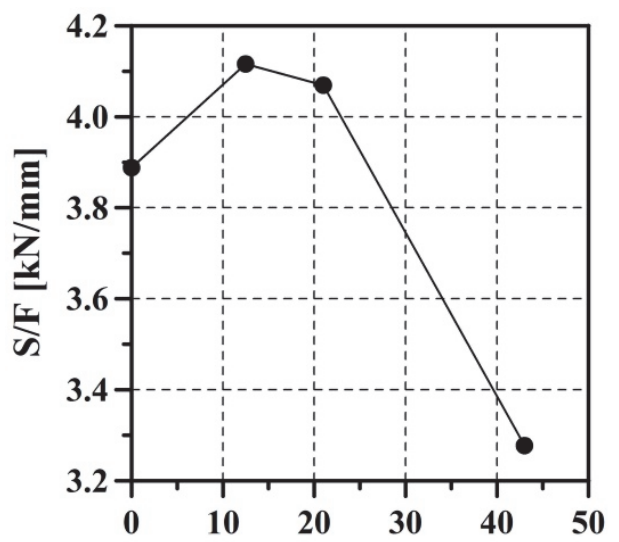

b) Aggregate replacement by BFS [\%]

Figure 3. Evolution of a) $\mathrm{S}$ and b) $\mathrm{S} / \mathrm{F}$ with the replacement of the aggregate by BFS

Table 9. Results of the indirect tensile test

\begin{tabular}{|c|c|c|c|c|}
\hline \multirow[b]{2}{*}{ Mixes } & \multirow[b]{2}{*}{$\begin{array}{c}\text { Air voids in the mix } \\
{[\%]}\end{array}$} & \multicolumn{2}{|c|}{ Condition } & \multirow[b]{2}{*}{$\begin{array}{l}\text { TSR } \\
{[\%]}\end{array}$} \\
\hline & & $\begin{array}{c}\text { ITD } \\
{[\mathrm{kPa}]}\end{array}$ & $\begin{array}{c}\text { ITS } \\
{[\mathrm{kPa}]}\end{array}$ & \\
\hline Control, BFS $=0 \%$ & 4.1 & 1001 & 837 & 83.6 \\
\hline $\mathrm{BFS}=12.5 \%$ & 5.2 & 1087 & 944 & 86.8 \\
\hline $\mathrm{BFS}=21 \%$ & 5.8 & 1033 & 892 & 86.4 \\
\hline $\mathrm{BFS}=43 \%$ & 9.0 & 890 & 684 & 76.9 \\
\hline
\end{tabular}

Table 10. Cantabro test results

\begin{tabular}{ccc}
\hline Mixture & Air voids in the mixture (\%) & Loss in Cantabro Test (\%) \\
\hline Control, BFS $=0 \%$ & 4.3 & 5.5 \\
BFS $=12.5 \%$ & 5.4 & 6.5 \\
BFS $=21 \%$ & 5.9 & 6.7 \\
BFS $=43 \%$ & 8.6 & 9.1 \\
\hline
\end{tabular}

Table 11. Results of Marshall tests, indirect traction and Cantabro

\begin{tabular}{|c|c|c|c|c|c|c|c|c|c|c|}
\hline \multirow[t]{2}{*}{ Mixing } & \multicolumn{6}{|c|}{ Marshall test } & \multicolumn{3}{|c|}{ Indirect Traction } & \multirow{2}{*}{$\begin{array}{c}\text { Cantabro } \\
\text { Loss [\%] }\end{array}$} \\
\hline & $\begin{array}{c}\mathrm{S} \\
{[\mathrm{kN}]}\end{array}$ & $\begin{array}{c}\mathbf{F} \\
{[\mathrm{mm}]}\end{array}$ & $\begin{array}{c}\mathrm{S} / \mathbf{F} \\
{[\mathrm{kN} / \mathrm{mm}]}\end{array}$ & $\begin{array}{c}\text { Va } \\
{[\%]}\end{array}$ & $\begin{array}{c}\text { VMA } \\
{[\%]}\end{array}$ & $\begin{array}{l}\text { VFA } \\
{[\%]}\end{array}$ & $\begin{array}{c}\text { ITD } \\
\text { [kPa] }\end{array}$ & $\begin{array}{c}\text { ITS } \\
{[\mathrm{kPa}]}\end{array}$ & $\begin{array}{l}\text { TSR } \\
{[\%]}\end{array}$ & \\
\hline Control & 13.62 & 3.51 & 3.89 & 4.2 & 16.7 & 74.8 & 1001 & 837 & 83,6 & 5.5 \\
\hline Control $-120^{\circ} \mathrm{C}$ & 11.11 & 4.15 & 2.68 & 7.0 & 19.1 & 63.5 & 811 & 625 & 77.1 & 9.8 \\
\hline WMA-Control & 13.95 & 3.55 & 3.93 & 4.5 & 16.9 & 73.4 & 1043 & 893 & 85.6 & 5.7 \\
\hline $\mathrm{BFS}-150^{\circ} \mathrm{C}$ & 14.15 & 3.48 & 4.07 & 5.8 & 17.3 & 66.7 & 1033 & 892 & 86.4 & 6.7 \\
\hline BFS $-120^{\circ} \mathrm{C}$ & 10.57 & 4.20 & 2.52 & 8.1 & 19.3 & 58.3 & 844 & 678 & 80.3 & 10.2 \\
\hline WMA-BFS & 14.62 & 3.51 & 4.17 & 6.0 & 17.5 & 65.6 & 1009 & 879 & 87.1 & 7.0 \\
\hline
\end{tabular}

The $21 \%$ substitution was chosen because in that percentage, the resistance under monotonic load in the Marshall test and under indirect traction was higher than the control mixture. Additionally, in practice, it would be of greater interest, from the environmental point of view, to use $21 \%$ of BFS compared to $12.5 \%$. In the table, for the purpose of comparison, the results of the tests performed on the control mixture manufactured at $150{ }^{\circ} \mathrm{C}$ and $120^{\circ} \mathrm{C}$ without the use of the HUSIL additive (called Control and Control- $120^{\circ} \mathrm{C}$, respectively) are also presented, and on the mixtures that used BFS $=21 \%$ manufactured at $150^{\circ} \mathrm{C}$ and $120^{\circ} \mathrm{C}$ (called BFS- $150^{\circ} \mathrm{C}$ and BFS- $120^{\circ}$ 
$\mathrm{C}$, respectively). Based on the results obtained, it is reported that: i) when the manufacturing temperature decreases, the mixtures remarkably decrease the resistance under monotonic load, moisture damage and abrasion; ii) the HUSIL additive helps to increase said resistances, and even the mixtures manufactured at $120^{\circ} \mathrm{C}$ (WMA) experience similar volumetric composition and monotonic load resistances slightly higher than those reached by those manufactured at $150^{\circ} \mathrm{C}$. The foregoing because the asphalt is stiffened when modified with the additive (see Tables 4-6); iii) the HUSIL additive helps to improve the handling and compactness of the mixtures due to the foaming effect (allowing an easier coating of the aggregate with the asphalt). The above is confirmed based on the decrease of Va observed in the mixtures manufactured at $120^{\circ} \mathrm{C}$; iv) Abrasion resistance reported from WMA is similar to that achieved by mixtures manufactured at $150^{\circ} \mathrm{C}$; WMAs reach greater resistance to indirect tensile stress (dry and submerged in water) compared to mixtures manufactured at $150^{\circ} \mathrm{C}$, even though the manufacturing temperature was $30^{\circ} \mathrm{C}$ lower. The above is mainly due to the effect of the additive, which perhaps has properties that allow to improve the adhesion between the aggregate and the asphalt. The above results are also indicators of greater resistance to moisture damage.

\section{Conclusions}

After presenting the results, you are in a position to evaluate and interpret their implications, especially with Based on the results obtained, it can be concluded for the case of the mixtures manufactured without the additive: i) As the blast furnace slag (BFS) are materials with greater porosity and absorption, air voids increased in the mixture analyzed; ii) In spite of the above, there is an increase in stiffness under monotonic load (stability, stability / flow ratio, indirect traction under dry and saturated condition, and ITS / ITD ratio) with respect to the control mixture, when mixtures were manufactured with replacement of $12.5 \%$ and $21 \%$ of the coarse aggregate by BFS (replacement of the sieves $1 / 2 "$, and $1 / 2 "$ and $3 / 8 "$, respectively). However, mixtures with BFS tend to have less resistance to abrasion.

In the case of the WMA mixtures manufactured with the additive, it is concluded: i) The HUSIL additive, when used in a proportion of $1 \%$ with respect to the asphalt mass, allowed to reduce the volume of voids with air (on mixtures with and without BFS) and increase the stiffness of the asphalt; ii) Using the additive, the manufacturing temperature of the mixtures can be lowered by $30^{\circ} \mathrm{C}$ and obtain a material with greater resistance under monotonic shred, to indirect traction (dry and submerged in water) and to moisture damage compared to the control mixture; iii) The above conclusion applies to the case where mixtures are made with $100 \%$ natural aggregate and for those where the coarse fraction is replaced by BFS in $21 \%$ (replacement of the sieves $1 / 2$ " and 3/8"); iv) WMA mixtures have resistance to abrasion similar to the control mixture; v) WMA mixtures meet the minimum quality requirements demanded by the Colombian specifications for the production of asphalt concrete mixtures in high traffic volumes.

\section{Acknowledgments}

The authors thank the research work teams of the Universidad Distrital Francisco José de Caldas, the Universidad Militar Nueva Granada, and the Universidad Nacional de Colombia (Manizales), who with their academic and research contributions and time invested, contributed to the culmination of this study.

\section{References}

Airey, G. D., Collop, A. C., \& Thom, N. H. (2004). Mechanical performance of asphalt mixtures incorporating slag and glass secondary aggregates. Proceedings of the 8th Conference on Asphalt Pavements (CAPSA'04). Sun City, South Africa. Retrieved from https://www.researchgate.net/publication/267718070

Akbarnejad, S., Houben, L. J. M., \& Molenaar, A. A. A. (2014). Application of aging methods to evaluate the longterm performance of road bases containing blast furnace slag materials. Road Materials and Pavement Design. 15(3), 488-506. https://doi.org/10.1080/14680629.2014.907196.

Al-Hdabi, A., \& Al Nageim, H. (2017). Improving asphalt emulsion mixtures properties containing cementitious filler by adding GGBS. Journal of Materials in Civil Engineering, 29(5), 04016297-1. https://doi.org/10.1061/(ASCE)MT.1943-5533.0001859.

Al-Rawashdeh, A. S., \& Sargand, S. (2014). Performance assessment of a warm asphalt binder in the presence of water by using surface free energy concepts and nanoscale techniques. Journal of Materials in Civil Engineering, 26(5), 803-811. https://doi.org/10.1061/(ASCE)MT.1943-5533.0000866.

Biro, S., Gandhi, T., \& Amirkhanian, S. (2009). Midrange temperature rheological properties of warm asphalt binders. Journal of Materials in Civil Engineering, 21(7), 316-323. https://doi.org//10.1061/(ASCE)08991561(2009)21:7(316). 
Bonaquist, R. (2011). Mix design practices for warm mix asphalt, NCHRP (Report 691), Transportation Research Board - TRB, Washington, D.C. Retrieved from http://co-asphalt.com/wpcontent/uploads/2015/03/nchrp_rpt_691.pdf

Cox, B. C., Smith, B. T., Howard, I. L., \& James, R. S. (2017). State of knowledge for Cantabro testing of dense graded asphalt. Journal of Materials in Civil Engineering, 29(10), 04017174. https://doi.org/10.1061/(ASCE)MT.1943-5533.0002020

Das, B., Prakash, S. Reddy, P. S. R., \& Misra, V. N. (2007). An overview of utilization of slag and sludge from steel industries. Resources, Conservation and Recycling, 50, 40-57. https://doi.org//10.1016/j.resconrec.2006.05.008

Farooq, M. A., Mir, M. S., \& Sharma, A. (2018). Laboratory study on use of RAP in WMA pavements using $\begin{array}{lllll}\text { rejuvenator. Construction } & \text { and }\end{array}$ https://doi.org/10.1016/j.conbuildmat.2018.02.079.

FHWA - Federal Highway Administration Research and Technology. (2008). Coordinating, developing, and delivering highway transportation innovations - User guidelines for waste and byproduct materials in pavement construction. Report Publication (Number: FHWA-RD-97-148). Retrieved from https://www.fhwa.dot.gov/publications/research/infrastructure/structures/97148/intro.cfm

Frigio, F., Raschia, S., Steiner, D., Hofko, B., \& Canestrari, F. (2016). Aging effects on recycled WMA porous $\begin{array}{lllll}\text { asphalt mixtures. Construction and Building Materials, 123, } & \text { 712-718. }\end{array}$ https://doi.org/10.1016/j.conbuildmat.2016.07.063.

Habal, A., \& Singh, D. (2017). Moisture damage resistance of GTR-Modified asphalt binders containing WMA additives using the Surface Free Energy approach. Journal of Performance of Constructed Facilities, 31(3). https://doi.org//10.1061/(ASCE)CF.1943-5509.0000995

Howard, I. L., Doyle, J. D., \& Cox, B. C. (2013). Merits of reclaimed asphalt pavement-dominated warm mixed flexible pavement base layers. Road Materials and Pavement Design, 14(S2), 106-128. https://doi.org//10.1080/14680629.2013.812834.

INVIAS - Instituto Nacional de Vías. (2013). Especificaciones Generales para Construcción de Carreteras. Bogotá D.C., Colombia.

Kim, D., Norouzi, A., Kass. S., Liske, T., \& Kim, R. (2017). Mechanistic performance evaluation of pavement sections containing RAP and WMA additives in Manitoba. Construction and Building Materials, 133, 39-50. https://doi.org/10.1016/j.conbuildmat.2016.12.035.

Liu, S., Cao, W., \& Fang, J. (2010). Orthogonal test research of asphalt rubber modified by warm asphalt additive, ICCTP 2010: Integrated Transportation Systems, Green Intelligent Reliable 2010, American Society of Civil Engineering, International Conference of Chinese Transportation Professionals (pp. 3480-3492). Beijing, China. https://doi.org//10.1061/41127(382)376

Modarres, A., \& Rahmanzadeh, M. (2014). Application of coal waste powder as filler in hot mix asphalt. Construction and Building Materials, 66, 476-483. https://doi.org/10.1016/j.conbuildmat.2014.06.002

Mohammad, L. N., Hassan, M. M., Vallabhu, B., \& Kabir, S. (2015). Louisiana's experience with WMA technologies: Mechanistic, environmental, and economic analysis. Journal of Materials in Civil Engineering, 27(6). https://doi.org//10.1061/(ASCE)MT.1943-5533.0001143

Muniandy, R., Aburkaba, E., \& Mahdi, L. (2013). Effect of mineral filler type and particle size on asphalt-filler mastic and stone mastic asphalt laboratory measured properties. Australian Journal of Basic Applied Sciences, 7(11), 475-487. Retrieved from http://www.ajbasweb.com/old/ajbas/2013/September/475-487.pdf

Nassar, A. I., Mohammed, M. K., Thom, N., \& Parry, T. (2016). Mechanical, durability and microstructure properties of Cold Asphalt Emulsion Mixtures with different types of filler. Construction and Building Materials, 114, 352-363. https://doi.org/10.1016/j.conbuildmat.2016.03.112.

Nouvion, S., Jullien, A., Sommier, M., \& Basuyau, V. (2009). Environmental modeling of blast furnace slag aggregate production. Road Materials and Pavement Design, 10(4), 715-745. https://doi.org/10.1080/14680629.2009.9690224.

Oluwasola, E. A., Hainin, M. R., \& Aziz, M. M. A. (2015). Evaluation of asphalt mixtures incorporating electric arc furnace steel slag and copper mine tailings for road construction. Transportation Geotechnics, 2, 47-55. https://doi.org//10.1016/j.trgeo.2014.09.004. 
Pasandín, A. R., \& Pérez, I. (2015). The influence of the mineral filler on the adhesion between aggregates and bitumen. International Journal of Adhesion and Adhesives, 58, 53-58. https://doi.org/10.1016/j.ijadhadh.2015.01.005.

Proctor, D. M., Fehling, K. A., Shay, E. C., Wittenborn, J. L., Avent, C., Bigham, R. D., Connolly, M., Lee, B., Shepker, T. O., \& Zak, M. A. (2000). Physical and chemical characteristics of blast furnace, basic oxygen furnace, and electric arc furnace steel industry slags. Environmental Science Technology, 34(8), 1576-1582. https://doi.org/10.1021/es9906002.

Ran, J., Xu, S., Li, M., \& Ji, J. (2010). Research on the performances of warm asphalt and warm mix asphalt with Sasobit, ICCTP 2010: Integrated Transportation Systems, Green Intelligent Reliable 2010, American Society of Civil Engineering, International Conference of Chinese Transportation Professionals (pp. 3725-3737). Beijing, China. https://doi.org//10.1061/41127(382)402

Robjent, L., \& Dosh, W. (2009). Warm-Mix asphalt for rural county roads, Cold Regions Engineering 2009: Cold Regions Impacts on Research, Design, and Construction. American Society of Civil Engineering (pp. 438454). Duluth, Minnesota, United States. https://doi.org//10.1061/41072(359)43

Rondón, H. A., Fernández, W. D., \& Zafra, C. (2016). Behavior of a warm mix asphalt using a chemical additive to foam the asphalt binder. Revista Facultad de Ingeniería, Universidad de Antioquia, 78, 129-138. https://doi.org/10.17533/udea.redin.n78a17.

Rondón, H. A., Fernández, W. D., \& Zafra, C., (2018b), Desarrollo de una mezcla asfáltica tibia bajo criterios técnicos y medioambientales. Bogotá D.C., Colombia, Ed. Espacios - Universidad Distrital Francisco José de Caldas, 124.

Rondón, H. A., Fernández, W. D., Ruge, J. C., Patiño, D., Vacca, H., \& Reyes, F. A. (2018a). Characterization of blast furnace slag for road projects. Revista Ingeniería de Construcción RIC, 33(1), 83-92. http://dx.doi.org/10.4067/S0718-50732018000100083.

Rondón, H. A., Noguera, J. A., \& Reyes, F. A. (2015). A review of warm mix asphalt technology: technical, economical and environmental aspects. Ingeniería e Investigación, 35(3), 5-18. http://dx.doi.org/10.15446/ing.investig.v35n3.50463.

Rondón, H. A., Ruge, J. C., Patiño, D., Vacca, H., Reyes, F. A., \& Farias, M. (2018). Use of blast furnace slag as a substitute for the fine fraction of aggregates in an asphalt mixture. Journal of Materials in Civil Engineering. Accepted to publish.

Sharma, A., Mir, M., \& Farooq, M. A. (2018). Performance of WMA additives under freeze-thaw action. Road Materials and Pavement Design, 1-13. https://doi.org/10.1080/14680629.2018.1444668.

Silva, H., Oliveira, J., Ferreira, C., \& Pereira, P. (2010). Assessment of the performance of warm mix asphalts in road pavements. International Journal of Pavement Research and Technology, 3(3), 119-127.

Singh, D., Ashish, P. K., Kataware, A., \& Habal, A. (2018). Effects of WMA additives and hydrated lime on highstress and high-temperature performance of Elvaloy ${ }^{\circledR}$ - and PPA-modified asphalt binder. Road Materials and Pavement Design. https://doi.org/10.1080/14680629.2018.1446040.

Sterling, V. (2012). Special mixture design considerations and methods for warm mix asphalt: a supplement to NCHRP Report 673: a manual for design of hot mix asphalt with commentary, National Cooperative Highway Research Program - NCHRP (Report 714). Washington, DC: Transportation Research Board. Retrieved from http://www.trb.org/Main/Blurbs/166517.aspx

Wang, G., Wang, Y., \& Gao, Z. (2010). Use of steel slag as a granular material: Volume expansion prediction and usability criteria. Journal of Hazardous Materials, 184(1-3), 555-560. https://doi.org/10.1016/j.jhazmat.2010.08.071.

You, Z., \& Goh, S. W. (2008). Laboratory evaluation of warm mix asphalt: a preliminary study. International Journal of Pavement Research and Technology, 1(1), 34-40. https://doi.org/10.6135/ijprt.org.tw/2008.1(1).34

Zhao, S., Huang, B., Shu, X., \& Moore, J. (2015). Effects of WMA technologies on asphalt binder blending. Journal of Materials in Civil Engineering, 28(2). https://doi.org/10.1061/(ASCE)MT.1943-5533.0001381.

Zhu, S., Chen, F., \& Yin, H. (2017). Simulation and validation of asphalt foaming process for virtual experiments and optimisation of WMA production. Road Materials and Pavement Design, 18(sup4), 144-164. https://doi.org/10.1080/14680629.2017.1389093 


\section{Copyrights}

Copyright for this article is retained by the author(s), with first publication rights granted to the journal.

This is an open-access article distributed under the terms and conditions of the Creative Commons Attribution license (http://creativecommons.org/licenses/by/3.0/). 